\title{
Phenolic and flavonoid content in ethanol extract and agro- morphological diversity of Curcuma aeruginosa accessions growing in West Java, Indonesia
}

\author{
NURUL KHUMAIDA ${ }^{1}$, MUHAMAD SYUKUR ${ }^{1}$, MARIA BINTANG ${ }^{2}$, WARAS NURCHOLIS ${ }^{2,3, \boldsymbol{v}}$ \\ ${ }^{1}$ Departement of Agronomy and Horticulture, Faculty of Agriculture, Institut Pertanian Bogor. Jl. Raya Dramaga, Kampus IPB Dramaga, Bogor 16680, \\ West Java, Indonesia \\ ${ }^{2}$ Department of Biochemistry, Faculty of Mathematics and Natural Sciences, Institut Pertanian Bogor. Jl. Raya Dramaga, Kampus IPB Dramaga, Bogor \\ 16680, West Java, Indonesia. Tel./fax.: +62-251-8423267, •email: wnurcholis@ apps.ipb.ac.id \\ ${ }^{3}$ Tropical Biopharmaca Research Center, Institut Pertanian Bogor. Jl. Taman Kencana No. 3, Kampus IPB Taman Kencana, Bogor 16128, West Java, \\ Indonesia
}

Manuscript received: 13 November 2018. Revision accepted: 12 February 2019.

\begin{abstract}
Khumaida N, Syukur M, Bintang M, Nurcholis W. 2019. Phenolic and flavonoid content in ethanol extract and agromorphological diversity of Curcuma aeruginosa accessions growing in West Java, Indonesia. Biodiversitas 20: 656-663. Curcuma aeruginosa is a rhizomatous medicinal plant with beneficial pharmacological activities. The aim of this work was to analyze the agromorphological, extract yield, and phenolic content of ten $C$. aeruginosa accessions which were collected from different locations in Indonesia. Cultivation was carried out in the open field in West Java of Indonesia using a completely randomized design. Qualitative and quantitative parameters were used to investigate agro-morphological traits. Total phenolic and total flavonoids contents were determined in ethanol extracts of samples. The plants were phenotypically diverse, in which there were significant variations among the ten $C$. aeruginosa accessions in number of leaves, plant height, number of shoots, fresh weight of rhizome, and dry weight of rhizome characters. Variability in the total phenolic and total flavonoid contents ranged from 29.08-46.92 mg GAE/g, and 21.31-33.81 mg QE/g, respectively. Six accessions had high phenolic content and extract yield. Therefore, these accessions could be utilized for commercial scale and also showed a high potency for medicinal plant breeding programs.
\end{abstract}

Keywords: Accessions, agro-morphology, Curcuma aeruginosa, flavonoid, phenolic

\section{INTRODUCTION}

In industry, the quality of the traditional medicine product is directly related to the quality of raw materials (Salgueiro et al. 2010). However, the quality of the raw material is dependent on the breeding plant program and also the practices in the agricultural system. Curcuma aeruginosa Roxb., namely temu ireng or temu hitam in Indonesia, is one of the most popular rhizomatous medicinal plant belonging to the family Zingiberaceae and genus Curcuma (Sasikumar 2005). The previous works had shown that the rhizome of $C$. aeruginosa has beneficial biological activities such as antioxidant (Nurcholis et al. 2015a), antimicrobial (Kamazeri et al. 2012; Akarchariya et al. 2017), hair-growth and skin lightening (Srivilai et al. 2017), anti-androgenic (Suphrom et al. 2012), uterine relaxant (Thaina et al. 2009), and anti-dengue (Moektiwardoyo et al. 2014). In this context, C. aeruginosa is an important raw material for an industry of traditional medicine. Presently, there are no identified Indonesian varieties of C. aeruginosa (MoA 2018). Thus, the development of $C$. aeruginosa varieties is needed to produce rhizome with the highest quality for industrial purposes.

Phenolics and flavonoids have been reported as the phytochemicals found in the rhizome of $C$. aeruginosa (Nurcholis et al. 2016a). A study has demonstrated that phenolics and flavonoids possess biological activities such as antioxidant (Al-Farsi et al. 2018), antimicrobial (Pandey et al. 2018), anticancer (Alaklabi et al. 2018), antiinflammatory and cytotoxic activity (Udavant et al. 2012). These properties make them particularly helpful for traditional medicine applications of $C$. aeruginosa rhizome. Thus, the quality of $C$. aeruginosa rhizome can be determined based on phenolics and flavonoids contents.

Research on the rhizomes of $C$. aeruginosa harvested from the different sites in Indonesia showed a high fluctuation in curcuminoid and cytotoxicity (Nurcholis et al. 2016b), phytochemical and rhizome color (Nurcholis et al. 2017), total phenolics and flavonoids contents (Nurcholis et al. 2016a). These studies suggested that the variation in bioactive content and biological activity can be influenced by several factors such as genetic and geographical variation. Also, some reports show that agromorphological traits are controlled by a genetic factor (Belaj et al. 2011; Bakić et al. 2017). In Indonesia, there is no comprehensive study of $C$. aeruginosa accessions for agro-morphological traits, phenolics and flavonoids contents, and extractable yield. The results of this study can form a guide to facilitate a selection scheme for breeding programs for identified new cultivars of $C$. aeruginosa. Therefore, this study evaluated the morphological attributes, extract yield, and phenolic contents of ten $C$. aeruginosa accessions with grown under the same 
environmental conditions, so that the results reflect genetically differences between accessions studied.

\section{MATERIALS AND METHODS}

\section{Plant material}

Ten rhizomes of $C$. aeruginosa accessions were collected from different regions in Indonesia in February 2015 (Table 1). Identification of plant specimens was conducted by taxonomist expert of the Biopharmaca Conservation and Cultivation Station, Tropical Biopharmaca Research Center, Bogor Agricultural University (IPB). A field experiment was carried out at the Biopharmaca Conservation and Cultivation Station, West Java of Indonesia $\left(6^{\circ} 32^{\prime} 25.47^{\prime \prime} \mathrm{N}\right.$ and $106^{\circ} 42^{\prime} 53.22^{\prime \prime} \mathrm{E}$, at 142.60 $m$ altitude), in December 2015. The experiment was arranged in a completely randomized design with threereplications. The plants were grown in the same soil conditions (latosol soil with $\mathrm{pH}$ of 4.5-5, organic $\mathrm{C}$ of $1.52 \%$, and $\mathrm{N}$ of $0.15 \%$ ) with plants spacing of $50 \mathrm{~cm} \times 50$ $\mathrm{cm}$. Two weeks before planting, the soil was treated with 1 $\mathrm{kg}$ cow manure per planting hole. Nine months after planting, in August 2016, the rhizomes were harvested.

\section{Agro-morphological evaluations}

Several qualitative and quantitative characters were measured to characterize $C$. aeruginosa accessions morphologically (Table 2). The characters were evaluated based on the set standards for traits by the Protection of Plant Varieties and Farmers' Rights Authority turmeric descriptor ( PPV-FRA 2011) with modification.

Table 1. Curcuma aeruginosa accessions used in this work with code, collection sites, and geographical coordinates

\begin{tabular}{|c|c|c|c|c|c|}
\hline Accession code/ Voucher specimens & Province & Location & Latitude (N) & Longitude (E) & Altitude (m) \\
\hline KL/BMK0049032015 & Central Java & Klewer & $7^{\circ} 35^{\prime} 05.66^{\prime \prime}$ & $110^{\circ} 49^{\prime} 45.38^{\prime \prime}$ & 96 \\
\hline PK/BMK0053032015 & Yogyakarta & Pakem & $7^{\circ} 39^{\prime} 55.46^{\prime \prime}$ & $110^{\circ} 25^{\prime} 11.30^{\prime \prime}$ & 424 \\
\hline BH/BMK0054032015 & Yogyakarta & Beringharjo & $7^{\circ} 47^{\prime} 56.40^{\prime \prime}$ & $110^{\circ} 22^{\prime} 01.56^{\prime \prime}$ & 115 \\
\hline GK/BMK0055032015 & Yogyakarta & Gunung Kidul & $7^{\circ} 58^{\prime} 04.87^{\prime \prime}$ & $110^{\circ} 36^{\prime} 09.67^{\prime \prime}$ & 180 \\
\hline KP/BMK0056032015 & Yogyakarta & Kulonprogo & $7^{\circ} 56 ' 25.03^{\prime \prime}$ & $110^{\circ} 14^{\prime} 20.30^{\prime \prime}$ & 20 \\
\hline PW/BMK0058032015 & Central Java & Purworejo & $7^{\circ} 44^{\prime} 25.35^{\prime \prime}$ & $110^{\circ} 01^{\prime} 59.00^{\prime \prime}$ & 56 \\
\hline MD/BMK0063032015 & East Java & Madura & $7^{\circ} 02^{\prime} 48.90^{\prime \prime}$ & $112^{\circ} 43^{\prime} 47.32^{\prime \prime}$ & 4 \\
\hline LC/BMK0064032015 & West Java & Losari Cirebon & $6^{\circ} 48^{\prime} 17.09^{\prime \prime}$ & $108^{\circ} 48^{\prime} 06.04^{\prime \prime}$ & 1 \\
\hline CB/BMK0065032015 & West Java & Ciampea Bogor & $6^{\circ} 32^{\prime} 35.89^{\prime \prime}$ & $106^{\circ} 41^{\prime} 22.41^{\prime \prime}$ & 148 \\
\hline MB/BMK0066032015 & Jambi & Muara Bungo & $1^{\circ} 37^{\prime} 00.61^{\prime \prime}$ & $102^{\circ} 22^{\prime} 16.28^{\prime \prime}$ & 65 \\
\hline
\end{tabular}

Table 2. List of the qualitative and quantitative (agro-morphological) characters used for the variability of the 10 C. aeruginosa accessions

\begin{tabular}{|c|c|c|}
\hline Variables & Details & Stage of observation \\
\hline \multicolumn{3}{|l|}{ Qualitative variables } \\
\hline Pseudostem habit (PSH) & 1: compact, 9: open & 150 DAP \\
\hline The color on pseudostem habit (CPSH) & 1: purple, 9: green & 150 DAP \\
\hline Venation pattern of the leaf (VPL) & 3: close, 5 : distant & 150 DAP \\
\hline Leaf disposition (LD) & 3: erect $\left(<45^{\circ}\right), 5$ : semi-erect $\left(45^{\circ}-85^{\circ}\right), 7$ : horizontal $\left(>85^{\circ}\right)$ & 150 DAP \\
\hline The margin of the leaf (ML) & 3: even, 5: wavy & 150 DAP \\
\hline Purple color on midrib (PCM) & $5: 50 \%$ of midrib, $7: 75 \%$ of midrib & $150 \mathrm{DAP}$ \\
\hline Blue color on rhizome (BCR) & 3: few, 5: medium, 7: many & At harvest (9 MAP) \\
\hline The habit of the rhizome (HR) & 3: compact, 5: intermediate, 7 : loose & At harvest (9 MAP) \\
\hline The shape of the rhizome (SR) & 3: straight, 5 : curved & At harvest (9 MAP) \\
\hline Status of the tertiary rhizome (STR) & 1: absent, 9: present & At harvest (9 MAP) \\
\hline Length of primary rhizome (LPR) & 3: short $(<5 \mathrm{~cm}), 5$ : medium $(5-10 \mathrm{~cm}), 7: \operatorname{long}(>10 \mathrm{~cm})$ & At harvest (9 MAP) \\
\hline Number of mother rhizome (NMR) & 1: one, 3: two-three, 5 : more than three & At harvest (9 MAP) \\
\hline Internode pattern of rhizome (IPR) & 3: close $(<1 \mathrm{~cm}), 5:$ distant $(>1 \mathrm{~cm})$ & At harvest (9 MAP) \\
\hline \multicolumn{3}{|l|}{ Quantitative variables } \\
\hline Plant height $(\mathrm{PH})$ & $\begin{array}{l}\text { Plant height }(\mathrm{cm}) \text { measured from the soil level to the tip of the leaf } \\
\text { of the main shoot }\end{array}$ & $150 \mathrm{DAP}$ \\
\hline Pseudostem diameter (PD) & Pseudostem diameter measured in $\mathrm{cm}$ & 150 DAP \\
\hline Number of leaves (NL) & Number of leaves per plant (no.) & 150 DAP \\
\hline Leaf length (LL) & Leaf length in $\mathrm{cm}$ & 150 DAP \\
\hline Leaf width (LW) & Leaf width in $\mathrm{cm}$ & 150 DAP \\
\hline Number of shoots (NS) & Number of shoot per plant (no.) & 150 DAP \\
\hline Fresh rhizome weight (FRW) & Rhizome fresh weight per plant $(\mathrm{kg})$ & At harvest (9 MAP) \\
\hline Dry rhizome weight (DRW) & Rhizome dry weight per plant $(\mathrm{kg})$ & At harvest (9 MAP) \\
\hline
\end{tabular}

\footnotetext{
Note: DAP: Days After Planting, MAP: Months After Planting
} 


\section{Extraction}

After harvesting, the fresh rhizome of each accession was cut, dried and crushed to a powder. The powder was extracted, and performed by the maceration method of Nurcholis et al. (2015b). Briefly, $25 \mathrm{~g}$ of the powdered material of each accession were macerated with $70 \%(\mathrm{v} / \mathrm{v})$ ethanol $(250 \mathrm{ml})$ at room temperature. After $24 \mathrm{~h}$, the accession solution was filtered using a Whatman filter paper (No. 4) and then subjected to evaporation (BUCHI, $\mathrm{R}-250$, Switzerland) at $50^{\circ} \mathrm{C}$. The extract yield of samples was calculated based on extract content $(\%, w / w)$.

\section{Phenolic and flavonoid content}

The total phenolics content of the ethanol extract was determined spectrophotometrically with the FolinCiocalteu method (Wan-Ibrahim et al. 2010). Extract sample $(10 \mu \mathrm{L})$ was added to a 96-well microplate containing $160 \mu \mathrm{L}$ distilled water. Then $10 \mu \mathrm{L}$ of FolinCiocalteu reagent $(10 \%)$ and $20 \mu \mathrm{L} \mathrm{Na}_{2} \mathrm{CO}_{3}(10 \%)$ solution were added and the mixture incubated for $30 \mathrm{~min}$ at room temperature. The absorbance of all accessions was measured at $750 \mathrm{~nm}$ using a microplate reader (Epoch BioTek, USA). All samples were analyzed in triplicate. Results of the total phenolic contents in extract samples were determined from a standard curve and expressed as $\mathrm{mg}$ of gallic acid equivalent per $\mathrm{g}$ of extract (mg GAE/g).

The total flavonoid content in ethanol extract of samples was determined spectrophotometrically using aluminum chloride reagent (Chang et al. 2002) with minor modification. The calibration curve was established using standard quercetin. Each extract or quercetin $(10 \mu \mathrm{L})$ in a 96-well microplate was added with methanol $(60 \mu \mathrm{L}), 10 \%$ aluminum chloride $(10 \mu \mathrm{L}), 1 \mathrm{M}$ potassium acetate $(10 \mu \mathrm{L})$ and distilled water $(120 \mu \mathrm{L})$, then the solution was incubated at room temperature for $30 \mathrm{~min}$. Finally, the absorbance was determined for all samples at a wavelength of $415 \mathrm{~nm}$ using a microplate reader (Epoch BioTek, USA). Total flavonoid content was calculated from a standard quercetin curve and expressed as quercetin equivalents ( $\mathrm{mg} \mathrm{QE} / \mathrm{g})$.

\section{Data analysis}

The qualitative characters data were subjected to ANOVA followed by the Kruskal-Wallis $\mathrm{H}$ test. The data of quantitative characteristic of agro-morphologically traits, rhizome extract, total phenolics content, and total flavonoids content were subjected to ANOVA followed by Duncan's multiple range test (DMRT). Statistical analysis was performed using the Statistical Tool for Agricultural Research (STAR) 2.0.1. All of the data were also analyzed using multivariate analysis, i.e., Bonferroni correlation, principal component analysis, and cluster analysis, performed by $\mathrm{R}$ software. Prior to analyses, data were normalized using log transformation and auto-scaling.

\section{RESULTS AND DISCUSSION}

\section{Agro-morphological characters}

There was no significant difference $(\mathrm{p}<0.05)$ among ten $C$. aeruginosa accessions based on the Kruskal Wallis rank sum test of the qualitative traits ( Table 3). The qualitative traits observed in the $C$. aeruginosa accessions were presented in Figure 1. The leaf disposition, blue color on the rhizome, number of mother rhizome, and internode pattern of rhizome characters showed the same pattern in all accessions. The blue color of rhizomes in this study was fewer than our previous study using samples from different geographical origin (Nurcholis et al. 2017). The accession MB has a difference for pseudostem habit, the color of the pseudostem habit, the margin of the leaf, venation pattern of the leaf, and purple color on the midrib when compared with other accessions. Based on the habit of the rhizome, the accessions $\mathrm{BH}, \mathrm{GK}$, and $\mathrm{MD}$ were found to be intermediate, whereas most accessions were loose. Regarding the shape of the rhizome, most accessions were straight, but the accession LC was curved. The majority of the accessions had a medium length for the primary rhizome, while the accessions KL, PW, and MD were long. Most accessions had a tertiary rhizome, but accessions MD and $\mathrm{CB}$ had no tertiary rhizome. The characteristics of qualitative agro-morphology were similar to the qualitative traits that were recorded by Setiadi et al. (2017). Jose and Thomas (2014) reported the presence of different morphological traits of $C$. aeruginosa including lateral spike position, purple color of the calyx, light pink color of the corolla, greenish blue color of the rhizome, dark purple color of leaf sheath, and purple-brown color of the midrib.

Table 3. Qualitative agro-morphological characters of the ten $C$. aeruginosa accessions

\begin{tabular}{|c|c|c|c|c|c|c|c|c|c|c|c|c|c|}
\hline \multirow{2}{*}{ Accession code ${ }^{a}$} & \multicolumn{13}{|c|}{ Qualitative agro-morphological characters ${ }^{\text {b }}$} \\
\hline & PSH & CPSH & LD & VPL & ML & PCM & NMR & BCR & HR & SR & LPR & IPR & STR \\
\hline KL & 9 & 9 & 3 & 5 & 5 & 5 & 5 & 3 & 7 & 3 & 7 & 5 & 9 \\
\hline PK & 9 & 9 & 3 & 5 & 5 & 5 & 5 & 3 & 7 & 3 & 5 & 5 & 9 \\
\hline BH & 9 & 9 & 3 & 5 & 5 & 5 & 5 & 3 & 5 & 3 & 5 & 5 & 9 \\
\hline GK & 9 & 9 & 3 & 5 & 5 & 5 & 5 & 3 & 5 & 3 & 5 & 5 & 9 \\
\hline $\mathrm{KP}$ & 9 & 9 & 3 & 5 & 5 & 5 & 5 & 3 & 7 & 3 & 5 & 5 & 9 \\
\hline PW & 9 & 9 & 3 & 5 & 5 & 5 & 5 & 3 & 7 & 3 & 7 & 5 & 9 \\
\hline MD & 9 & 9 & 3 & 5 & 5 & 5 & 5 & 3 & 5 & 3 & 7 & 5 & 1 \\
\hline $\mathrm{LC}$ & 9 & 9 & 3 & 5 & 5 & 5 & 5 & 3 & 7 & 5 & 5 & 5 & 9 \\
\hline CB & 9 & 9 & 3 & 5 & 5 & 5 & 5 & 3 & 7 & 3 & 5 & 5 & 1 \\
\hline MB & 1 & 1 & 3 & 3 & 3 & 7 & 5 & 3 & 7 & 3 & 5 & 5 & 9 \\
\hline $\mathrm{H}$ & $9.0 \mathrm{~ns}$ & $9.0 \mathrm{~ns}$ & $9.0 \mathrm{~ns}$ & $9.0 \mathrm{~ns}$ & $9.0 \mathrm{~ns}$ & $9.0 \mathrm{~ns}$ & $9.0 \mathrm{~ns}$ & $9.0 \mathrm{~ns}$ & $9.0 \mathrm{~ns}$ & $9.0 \mathrm{~ns}$ & $9.0 \mathrm{~ns}$ & $9.0 \mathrm{~ns}$ & $9.0 \mathrm{~ns}$ \\
\hline
\end{tabular}

Note: $\mathrm{H}=$ value of Kruskal Wallis test; $\mathrm{ns}=$ nonsignificant at the 0.05 probability level; ${ }^{\mathrm{a}, \mathrm{b}}$ For an explanation of accessions code and character symbols, see Table 1 and Table 2 respectively 


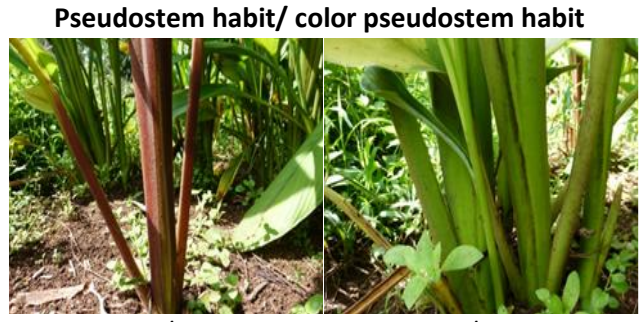

Compact/ purple

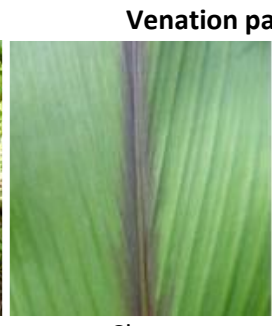

Close

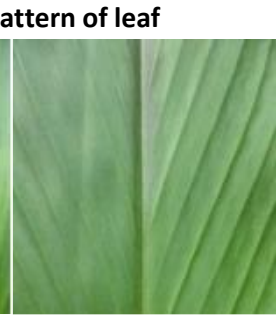

Distant

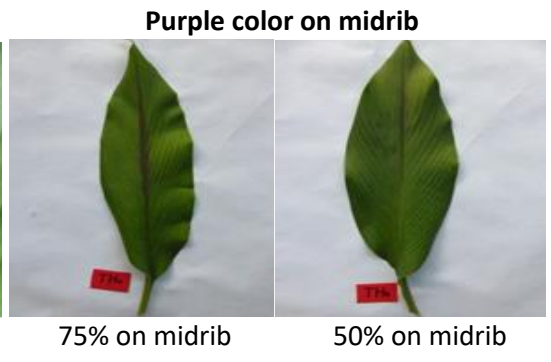

The shape of the rhizome

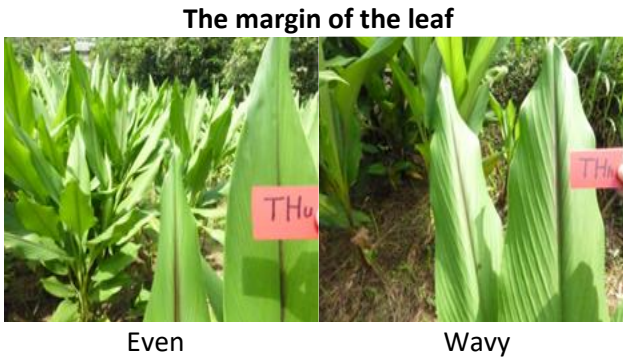

The habit of the rhizome

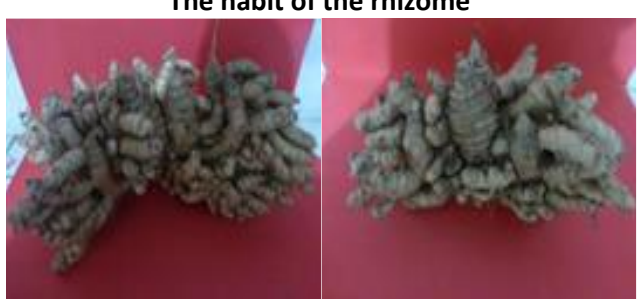

Loose

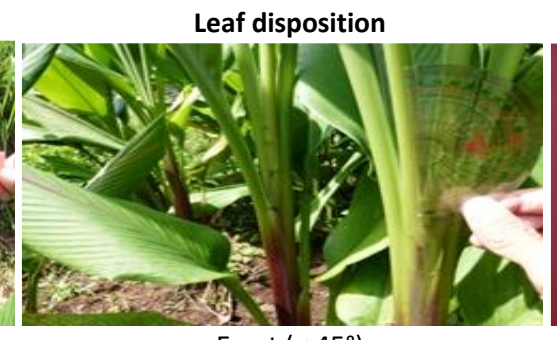

Erect $\left(<45^{\circ}\right)$

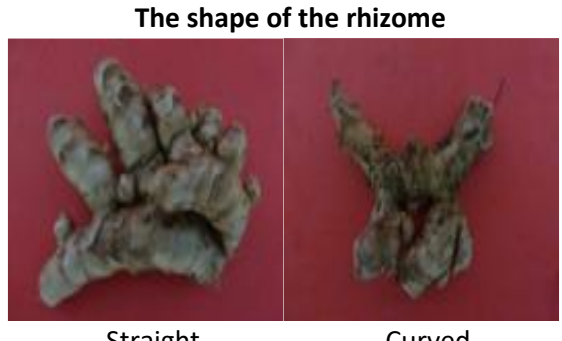

Straight

Curved

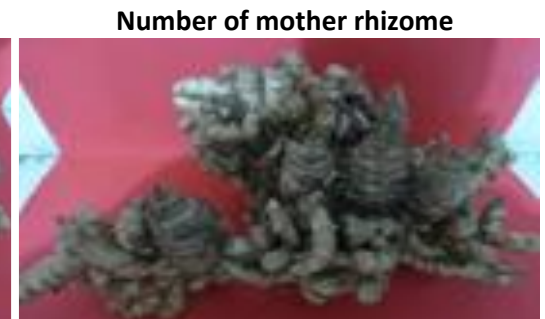

$>3$ mother rhizomes
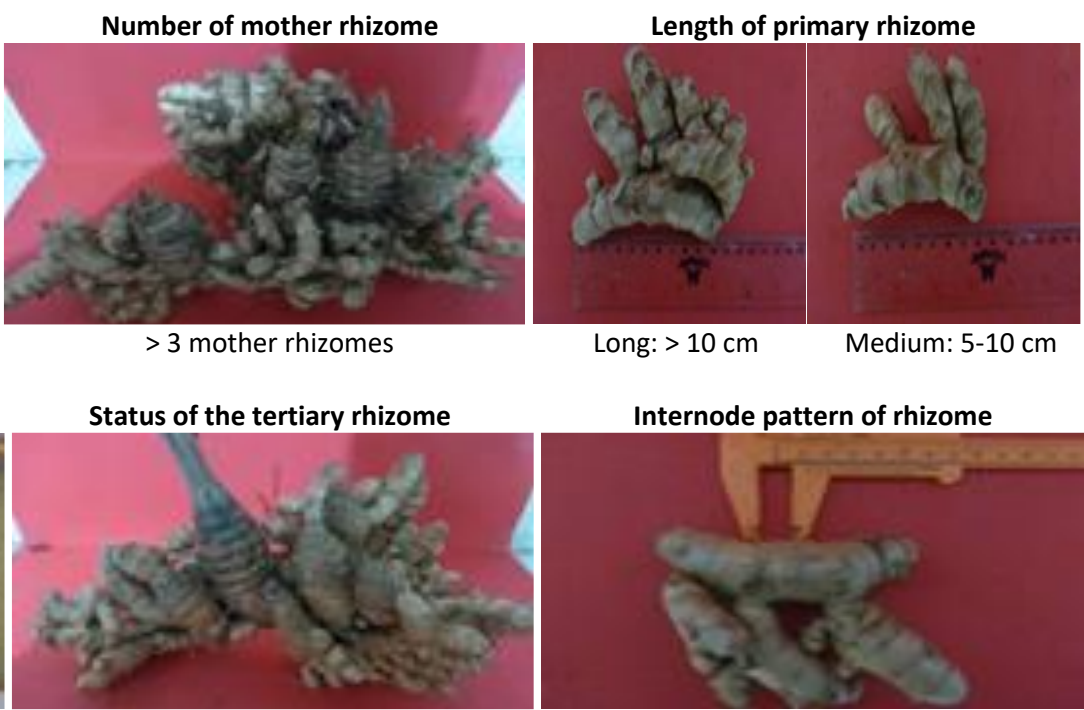

Absent

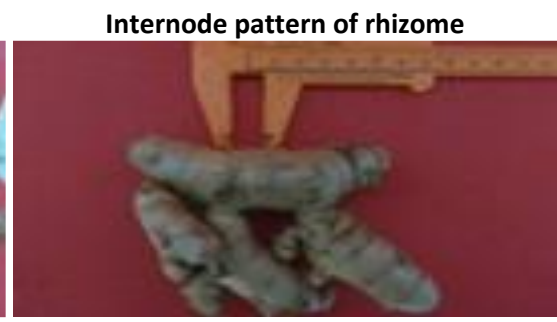

Distant: $>1 \mathrm{~cm}$

Figure 1. Variation in the qualitative morphology of C. aeruginosa

The quantitative traits of the $C$. aeruginosa accessions significantly varied $(\mathrm{p}<0.05)$ except for pseudostem diameter, leaf length, and leaf width (Table 4). The accession PW displayed highest plant height $(179.14 \mathrm{~cm})$, pseudostem diameter $(3.51 \mathrm{~cm})$, number of shoots $(9.75)$, and fresh rhizome weight $(3.90 \mathrm{~kg} /$ plants $)$. The fresh and dry rhizome weight in the current study were contrastingly different from those reported by Setiadi et al. (2017) with values of 0.31 and $0.18 \mathrm{~kg} / \mathrm{plants}$, respectively. Variation in agro-morphological character is affected by environmental (Mohammadi and Asadi-Gharneh 2018), developmental (Anandan et al. 2018), and genetical (Neugart et al. 2018) factors.

\section{Extract yield}

Ethanol extract yield was varied significantly $(\mathrm{p}<0.05)$ in different accessions (Table 5). The accession PK exhibited the highest $(7.36 \%$, w/w) ethanol extract yield, in which the accession LC was the lowest one $(3.68 \%, \mathrm{w} / \mathrm{w})$.
The extract yield in this study was considerably lower than our previous research (7.92 to $19.71 \%$, w/w) using the sample from a different geographic origin (Nurcholis et al. 2017). The extract yield in this study was also lower than those reported for $C$. aeruginosa by Moektiwardoyo et al. (2014) $(24.13 \%$, w/w) using the sample originated from Bandung. Extract yield is influenced by maceration time (Petropulos et al. 2014). Moektiwardoyo et al. (2014) used three days for maceration time, while in this study was two days.

Furthermore, the accessions in this research were cultivated in the same condition and extracted by technically the same method. Thus, the variation of extract yield is possibly influenced by the genetic factor in this case. The extract yield affected by genetic factor was also reported in other plant species such as Camelina sativa (Kurasiak-Popowska et al. 2018), Vigna radiata (Wang et al. 2018), Curcuma zanthorrhiza (Nurcholis et al. 2018), and Curcuma zedoaria (Syahid and Heryanto 2017). 
Table 4. Quantitative agro-morphological characters of the ten C. aeruginosa accessions

\begin{tabular}{|c|c|c|c|c|c|c|c|c|}
\hline \multirow{2}{*}{ Accession code $^{a}$} & \multicolumn{8}{|c|}{ Quantitative agro-morphological characters ${ }^{\text {b }}$} \\
\hline & PH (cm) & PD (cm) & NL (no.) & LL (cm) & LW (cm) & NS (no.) & FRW (kg/plants) & DRW (kg/plants) \\
\hline KL & $164.99 \mathrm{ab}$ & $3.42 \mathrm{a}$ & $9.33 \mathrm{ab}$ & $77.14 \mathrm{a}$ & $17.04 \mathrm{a}$ & $4.83 \mathrm{~cd}$ & $2.50 \mathrm{ab}$ & $0.49 \mathrm{ab}$ \\
\hline PK & $164.39 \mathrm{ab}$ & $3.12 \mathrm{a}$ & $9.09 \mathrm{ab}$ & $76.89 \mathrm{a}$ & $15.94 \mathrm{a}$ & $3.91 \mathrm{~d}$ & $1.80 \mathrm{~b}$ & $0.37 \mathrm{~b}$ \\
\hline $\mathrm{BH}$ & $160.33 b$ & $3.17 \mathrm{a}$ & $9.31 \mathrm{ab}$ & $73.26 \mathrm{a}$ & $15.58 \mathrm{a}$ & $4.54 d$ & $2.10 \mathrm{~b}$ & $0.40 \mathrm{~b}$ \\
\hline GK & $165.30 \mathrm{ab}$ & $3.42 \mathrm{a}$ & $9.67 \mathrm{a}$ & $73.89 \mathrm{a}$ & $16.51 \mathrm{a}$ & $4.44 d$ & $2.13 \mathrm{ab}$ & $0.41 \mathrm{~b}$ \\
\hline $\mathrm{KP}$ & $172.49 \mathrm{ab}$ & $3.30 \mathrm{a}$ & $8.23 b c$ & $78.74 \mathrm{a}$ & $21.37 \mathrm{a}$ & $6.31 \mathrm{bcd}$ & $2.90 \mathrm{ab}$ & $0.55 \mathrm{ab}$ \\
\hline PW & $179.14 \mathrm{a}$ & $3.51 \mathrm{a}$ & $9.25 \mathrm{ab}$ & $77.50 \mathrm{a}$ & $16.89 \mathrm{a}$ & $9.75 \mathrm{a}$ & $3.90 \mathrm{a}$ & $0.67 \mathrm{ab}$ \\
\hline MD & $168.99 \mathrm{ab}$ & $3.19 \mathrm{a}$ & $8.50 \mathrm{abc}$ & $75.09 \mathrm{a}$ & $15.98 \mathrm{a}$ & $6.33 \mathrm{bcd}$ & $3.22 \mathrm{ab}$ & $0.60 \mathrm{ab}$ \\
\hline $\mathrm{LC}$ & $176.53 \mathrm{ab}$ & $3.48 \mathrm{a}$ & $8.75 \mathrm{abc}$ & $77.27 \mathrm{a}$ & $16.95 \mathrm{a}$ & $7.75 \mathrm{abc}$ & $3.10 \mathrm{ab}$ & $0.75 \mathrm{a}$ \\
\hline $\mathrm{CB}$ & $165.49 \mathrm{ab}$ & $2.86 \mathrm{a}$ & $7.79 \mathrm{c}$ & $74.54 \mathrm{a}$ & $15.29 \mathrm{a}$ & $5.57 \mathrm{bcd}$ & $2.17 \mathrm{ab}$ & $0.43 b$ \\
\hline MB & $176.33 \mathrm{ab}$ & $2.91 \mathrm{a}$ & $7.71 \mathrm{c}$ & $79.41 \mathrm{a}$ & $16.14 \mathrm{a}$ & $8.14 \mathrm{ab}$ & $2.07 \mathrm{~b}$ & $0.38 b$ \\
\hline
\end{tabular}

Note: Different letters in column indicating statistically differences mean at $P<0.05$ by Duncan's multiple range test. a,bFor an explanation of accessions code and character symbols, see Table 1 and Table 2 respectively

\section{Phenolic and flavonoid content}

Significant differences were detected among the accessions for phenolics and flavonoids contents (Table 5). The highest total phenolic content (46.92 mg GAE/g) was recorded in $\mathrm{PK}$, whereas the accession KP had the lowest (29.08 $\mathrm{mg} \mathrm{GAE} / \mathrm{g}$ ). Total flavonoid content ranged from $21.31 \mathrm{mg} \mathrm{QE} / \mathrm{g}(\mathrm{MB})$ to $33.81 \mathrm{mg} \mathrm{QE} / \mathrm{g}(\mathrm{GK})$. The previous study reported various ranges of total phenolic content (26.70 to $70.83 \mathrm{mg} \mathrm{GAE} / \mathrm{g}$ ) and total flavonoid content $(7.65-21.71 \mathrm{mg} \mathrm{QE} / \mathrm{g})$ in the samples collected from the different geographical origin (Nurcholis et al. 2016a). Environmental factors and plant species can profoundly affect the metabolite production in medicinal plants (Oliveira et al. 2013; Moghaddam and Mehdizadeh 2015; Moghaddam and Pirbalouti 2017; Nurcholis et al. 2018). The present study was conducted in the same environment and cultivation; therefore a possible reason for total phenolic and flavonoid content variations is the genetic factor.
Table 5. Variation in ethanol extract yield, total phenolic and total flavonoid contents of ten $C$. aeruginosa accessions

\begin{tabular}{lccc}
\hline $\begin{array}{l}\text { Accession } \\
\text { code }^{\text {a }}\end{array}$ & $\begin{array}{c}\text { Extract } \\
\text { yield }(\%)\end{array}$ & $\begin{array}{c}\text { Total phenolic } \\
(\mathbf{m g ~ G A E} / \mathbf{g})\end{array}$ & $\begin{array}{c}\text { Total flavonoid } \\
(\mathbf{m g} \text { QE/g) }\end{array}$ \\
\hline $\mathrm{KL}$ & $6.01 \mathrm{ab}$ & $32.08 \mathrm{ab}$ & $22.14 \mathrm{~b}$ \\
$\mathrm{PK}$ & $7.36 \mathrm{a}$ & $46.92 \mathrm{a}$ & $23.53 \mathrm{~b}$ \\
$\mathrm{BH}$ & $6.47 \mathrm{ab}$ & $35.08 \mathrm{ab}$ & $26.03 \mathrm{ab}$ \\
$\mathrm{GK}$ & $6.43 \mathrm{ab}$ & $40.42 \mathrm{ab}$ & $33.81 \mathrm{a}$ \\
$\mathrm{KP}$ & $6.54 \mathrm{ab}$ & $29.08 \mathrm{~b}$ & $23.53 \mathrm{~b}$ \\
$\mathrm{PW}$ & $5.43 \mathrm{ab}$ & $30.42 \mathrm{~b}$ & $27.42 \mathrm{ab}$ \\
MD & $6.84 \mathrm{ab}$ & $31.08 \mathrm{~b}$ & $23.53 \mathrm{~b}$ \\
LC & $3.68 \mathrm{~b}$ & $37.92 \mathrm{ab}$ & $27.42 \mathrm{ab}$ \\
$\mathrm{CB}$ & $4.85 \mathrm{ab}$ & $40.08 \mathrm{ab}$ & $27.14 \mathrm{ab}$ \\
$\mathrm{MB}$ & $6.26 \mathrm{ab}$ & $32.58 \mathrm{ab}$ & $21.31 \mathrm{~b}$ \\
\hline
\end{tabular}

Note: Different letters in column indicate statistical differences mean at $P<0.05$ by Duncan's multiple range test. For an explanation of accessions code, see Table 1

Table 6. Correlation coefficients among agro-morphology traits, extract yield, total phenolic content and total flavonoid content on ten C. aeruginosa accessions

\begin{tabular}{|c|c|c|c|c|c|c|c|c|c|c|c|c|c|c|c|c|c|c|c|}
\hline & CPSH & VPL & ML & PCM & HR & SR & LPR & STR & PH & PD & NL & LL & LW & NS & FRW & DRW & Ext. & Phe. & Fla. \\
\hline$\overline{\mathrm{PSH}}$ & $1.00 * * *$ & $1.00 * * *$ & $1.00^{* * *}$ & $-1.00 * * *$ & -0.22 & 0.11 & 0.22 & -0.17 & -0.38 & 0.50 & 0.54 & -0.52 & 0.13 & -0.37 & 0.27 & 0.33 & -0.089 & 0.19 & 0.41 \\
\hline $\mathrm{CPSH}$ & & $1.00 * * *$ & $1.00 * * *$ & $-1.00 * * *$ & -0.22 & 0.11 & 0.22 & -0.17 & -0.38 & 0.50 & 0.54 & -0.52 & 0.13 & -0.37 & 0.27 & 0.33 & -0.089 & 0.19 & 0.41 \\
\hline VPL & & & $1.00 * * *$ & $-1.00 * * *$ & -0.22 & 0.11 & 0.22 & -0.17 & -0.38 & 0.50 & 0.54 & -0.52 & 0.13 & -0.37 & 0.27 & 0.33 & -0.089 & 0.19 & 0.41 \\
\hline ML & & & & $-1.00^{* * *}$ & -0.22 & 0.11 & 0.22 & -0.17 & -0.38 & 0.50 & 0.54 & -0.52 & 0.13 & -0.37 & 0.27 & 0.33 & -0.089 & 0.19 & 0.41 \\
\hline PCM & & & & & 0.22 & -0.11 & -0.22 & 0.17 & 0.38 & -0.50 & -0.54 & 0.52 & -0.13 & 0.37 & -0.27 & -0.33 & 0.089 & -0.19 & -0.41 \\
\hline HR & & & & & & 0.22 & -0.048 & 0.22 & 0.49 & -0.069 & -0.40 & $0.76^{*}$ & 0.30 & 0.38 & 0.11 & 0.18 & -0.38 & 0.0048 & -0.42 \\
\hline SR & & & & & & & -0.22 & 0.17 & 0.39 & 0.37 & -0.0057 & 0.15 & 0.037 & 0.30 & 0.27 & $0.65^{*}$ & $-0.76^{*}$ & 0.15 & 0.18 \\
\hline LPR & & & & & & & & -0.22 & 0.18 & 0.41 & 0.27 & 0.068 & -0.053 & 0.30 & $0.64 *$ & 0.43 & 0.068 & -0.53 & -0.23 \\
\hline STR & & & & & & & & & 0.18 & 0.49 & 0.48 & 0.40 & 0.35 & 0.058 & -0.084 & -0.04 & 0.07 & -0.0013 & 0.036 \\
\hline $\mathrm{PH}$ & & & & & & & & & & 0.26 & -0.34 & $0.73^{*}$ & 0.34 & $0.94 * * *$ & $0.68 *$ & $0.66^{*}$ & -0.45 & -0.45 & -0.11 \\
\hline PD & & & & & & & & & & & $0.72 *$ & 0.057 & 0.37 & 0.19 & 0.60 & $0.64 *$ & -0.22 & -0.23 & 0.38 \\
\hline NL & & & & & & & & & & & & -0.40 & -0.10 & -0.33 & 0.064 & 0.045 & 0.18 & 0.19 & 0.47 \\
\hline LL & & & & & & & & & & & & & 0.53 & 0.56 & 0.26 & 0.25 & -0.072 & -0.36 & -0.59 \\
\hline LW & & & & & & & & & & & & & & 0.16 & 0.34 & 0.31 & 0.065 & -0.48 & -0.16 \\
\hline NS & & & & & & & & & & & & & & & $0.74 *$ & $0.65^{*}$ & -0.49 & -0.56 & -0.10 \\
\hline FRW & & & & & & & & & & & & & & & & $0.90 * * *$ & -0.37 & -0.63 & 0.042 \\
\hline DRW & & & & & & & & & & & & & & & & & -0.61 & -0.42 & 0.088 \\
\hline Extract & & & & & & & & & & & & & & & & & & 0.027 & -0.29 \\
\hline Phenolic & & & & & & & & & & & & & & & & & & & 0.35 \\
\hline
\end{tabular}

Note: For explanation character symbols, see Table $2 . *, * * * *$ Significant at $0.05,0.01$, and 0.001 probability levels after Bonferroniadjustment, respectively 


\section{Multivariate analyses}

The determination of selection characters is important in plant breeding program (Acquaah 2017). Correlations between the investigated agro-morphology traits, extract yield, phenolics content of $C$. aeruginosa accessions were shown in Table 6 . Results showed a positive and significant $(\mathrm{p} \leq 0.001)$ correlation between pseudostem habit $(\mathrm{PSH})$, the color on pseudostem habit $(\mathrm{CPSH})$, venation pattern of the leaf (VPL), and the margin of the leaf (ML); plant height $(\mathrm{PH})$ and the number of shoots (NS) $(\mathrm{r}=0.94)$. Fresh rhizome weight (FRW), which is an important characteristic in $C$. aeruginosa medicinal plant breeding of harvestable rhizomes, exhibited a significant $(\mathrm{p} \leq 0.05)$ positive correlation with NS $(r=0.74), \mathrm{PH}(\mathrm{r}=0.68)$, and length of the primary rhizome (LPR) $(r=0.64)$. Moreover, dry rhizome weight (DRW) was significantly positively correlated with FRW $(\mathrm{r}=0.90, \mathrm{p} \leq 0.001)$, NS $(\mathrm{r}=0.65, \mathrm{p}$ $\leq 0.05)$, pseudostem diameter (PD) $(\mathrm{r}=0.64, \mathrm{p} \leq 0.05), \mathrm{PH}$ $(\mathrm{r}=0.66, \mathrm{p} \leq 0.05)$, and the shape of the rhizome (SR) $(\mathrm{r}=$ $0.65, \mathrm{p} \leq 0.05$ ). Leaf length (LL) was positively correlated $(\mathrm{p} \leq 0.05)$ with $\mathrm{PH}(\mathrm{r}=0.73)$ and the habit of the rhizome (HR) $(r=0.76)$. PD and number of leaves (NL) showed significant $(\mathrm{p} \leq 0.05)$ positive correlation $(\mathrm{r}=0.72)$. Purple color on midrib (PCM) was significantly ( $\mathrm{p} \leq 0.001)$ negative correlated with PSH, CPSH, VPL, and ML. The extract yield with SR $(r=-0.76)$ and DRW $(r=-0.61)$ showed a significant $(\mathrm{p} \leq 0.05)$ negatively correlation, as for total phenolic content with NS $(r=-0.56)$ and FRW $(r=$ $-0.63)$ and between total flavonoid content and LL ( $\mathrm{r}=$ 0.59). The improvement leading to produce a high yield extract and metabolite content such as phenolics are the main objective of plant breeding in C. aeruginosa. Therefore, SR, DRW, NS, and FRW can be suggested as an important selection criterion in $C$. aeruginosa for good extraction and bioactive yields. Similar result was obtained by Mishra et al., (2018) who found selection criteria such as the fresh weight of rhizome, dry weight of rhizome and plant height for improvement rhizome yield of C. longa.

The principal component analysis (PCA) was conducted using agro-morphology traits, extract yield, and phenolic content. The PCA allows the identification of patterns showing similarities and differences in data of the accessions studied (Kwarteng et al. 2018; Mirto et al. 2018). The first five principal components accounted for $90.041 \%$ of the cumulative contribution (total variability) (Table 7). PC-1 had 6.963 variance (Eigenvalue) which is $34.813 \%$ of total variation explained (Table 7). Purple color on leaf midrib (0.364), habit of the rhizome (0.153), status of the tertiary rhizome (0.044), plant height $(0.179)$, leaf length $(0.247)$, leaf width $(0.003)$, number of shoots (0.173) and extract yield (0.023) contributed positively to PC1. In contrast, pseudostem habit (-0.364), color on pseudostem habit $(-0.364)$, venation pattern of the leaf ($0.364)$, margin of the leaf $(-0.364)$, shape of the rhizome (-
0.036), length of primary rhizome (-0.075), pseudostem diameter $(-0.205)$, number of leaves $(-0.261)$, fresh rhizome weight $(-0.072)$, dry rhizome weight $(-0.100)$, phenolic ($0.093)$ and flavonoid $(-0.217)$ contributed negatively to PC1. PC-2 contributed $26.139 \%$ of the total variation and demonstrated positively in the various traits such as purple color on midrib (0.051), number of leaves (0.015), extract yield (0.235), phenolic (0.262) and flavonoid (0.017). However, traits which correlated negatively to PC-2 were pseudostem habit $(-0.051)$, color on pseudostem habit ($0.051)$, venation pattern of the leaf $(-0.051)$, margin of the leaf $(-0.051)$, habit of the rhizome $(-0.173)$, shape of the rhizome (-0.218), length of primary rhizome (-0.193), status of the tertiary rhizome $(-0.062)$, plant height ($0.354)$, pseudostem diameter $(-0.264)$, leaf length $(-0.236)$, leaf width (-0.231), number of shoots (-0.345), fresh rhizome weight $(-0.398)$ and dry rhizome weight $(-0.404)$. PC-3, PC-4, and PC5 contributed $11.181 \%, 9.896 \%$, and $8.012 \%$ to the total variation, respectively.

Two-dimensional hierarchical cluster analysis (HCA) was conducted to compare with the results from PCA (Péroumal et al. 2017). The HCA allowed the relationship between the accessions studied and the studied traits to identify which of these are the most powerful (Bakić et al. 2017). Three groups were defined as shown in Figure 2. Group 1 composed only one accession (MB) with high PCM and LL traits but also low CPSH, PSH, VPL and ML traits. Group 2 was composed of three accessions: KP, PW, and LC. These accessions showed the highest DRW, FRW, NS, PH, SR and LW traits. Group 3 was comprised of MD, $\mathrm{CB}, \mathrm{BH}, \mathrm{GK}, \mathrm{KL}$, and $\mathrm{PK}$ accessions. These accessions were characterized by high total phenolic content, total flavonoid content, and extract yield. Thus, these accessions have the potential to be deployed in plant breeding programs on a commercial scale. In the second dimension, three main clusters were defined. The first group consisted of PCM, HR, LL, STR, LW, SR, PH, NS, FRW, and DRW characters. Extract yield and LPR traits were grouped in the second cluster. The third cluster contained the traits for total phenolic content, total flavonoid content, ML, VPL, $\mathrm{PSH}, \mathrm{CPSH}, \mathrm{PD}$, and NL.

In this study, the $C$. aeruginosa accessions exhibited variations of agro-morphological traits, i.e., fresh weight of the rhizome, number of leaves, plant height, number of shoots and dry weight of rhizome. The shape of the rhizome, number of shoots, fresh rhizome weight and dry rhizome weight could be used as an important selection criterion in $C$. aeruginosa breeding for obtaining high extract and phenolics content. The accessions of MD, CB, $\mathrm{BH}, \mathrm{GK}, \mathrm{KL}$, and $\mathrm{PK}$ produced high extract yield, total flavonoid, and total phenolic contents. These accessions are recommended for breeding programs resulting in high extract and the bioactive yield for commercial scale. 
Table 7. Eigenvectors, Eigenvalues and proportion of variation explained by first five components for different agro-morphology traits, extract yield, total phenolic, and total flavonoid contents of C. aeruginosa accessions

\begin{tabular}{|c|c|c|c|c|c|}
\hline \multirow{2}{*}{ Variable $^{\text {a }}$} & \multicolumn{5}{|c|}{ Eigenvectors } \\
\hline & PC-1 & PC-2 & PC-3 & PC-4 & PC-5 \\
\hline PSH & -0.364 & -0.051 & 0.014 & 0.026 & 0.180 \\
\hline $\mathrm{CPSH}$ & -0.364 & -0.051 & 0.014 & 0.026 & 0.180 \\
\hline VPL & -0.364 & -0.051 & 0.014 & 0.026 & 0.180 \\
\hline ML & -0.364 & -0.051 & 0.014 & 0.026 & 0.180 \\
\hline PCM & 0.364 & 0.051 & -0.014 & -0.026 & -0.180 \\
\hline HR & 0.153 & -0.173 & -0.158 & -0.130 & 0.493 \\
\hline SR & -0.036 & -0.218 & -0.486 & -0.034 & -0.039 \\
\hline LPR & -0.075 & -0.193 & 0.419 & 0.187 & -0.161 \\
\hline STR & 0.044 & -0.062 & -0.052 & -0.662 & -0.147 \\
\hline $\mathrm{PH}$ & 0.179 & -0.354 & -0.088 & 0.005 & -0.092 \\
\hline PD & -0.205 & -0.264 & 0.048 & -0.325 & -0.246 \\
\hline NL & -0.261 & 0.015 & 0.086 & -0.355 & -0.347 \\
\hline LL & 0.247 & -0.236 & 0.053 & -0.242 & 0.268 \\
\hline LW & 0.003 & -0.231 & 0.168 & -0.325 & 0.335 \\
\hline NS & 0.173 & -0.345 & -0.041 & 0.177 & -0.165 \\
\hline FRW & -0.072 & -0.398 & 0.138 & 0.166 & -0.108 \\
\hline DRW & -0.100 & -0.404 & -0.044 & 0.135 & -0.035 \\
\hline Extract yield & 0.023 & 0.235 & 0.485 & -0.164 & 0.008 \\
\hline Phenolic & -0.093 & 0.262 & -0.409 & -0.074 & 0.078 \\
\hline Flavonoid & -0.217 & 0.017 & -0.292 & -0.007 & -0.355 \\
\hline Eigen value & 6.963 & 5.228 & 2.236 & 1.979 & 1.602 \\
\hline $\begin{array}{l}\text { Proportion of variation } \\
\text { explained (\%) }\end{array}$ & 34.813 & 26.139 & 11.181 & 9.896 & 8.012 \\
\hline $\begin{array}{l}\text { Cumulative proportio } \\
\text { of variation }(\%)\end{array}$ & 34.813 & 60.952 & 72.133 & 82.029 & 90.041 \\
\hline
\end{tabular}

Note: ${ }^{\text {aFor }}$ an explanation of variable symbols, see Table 2

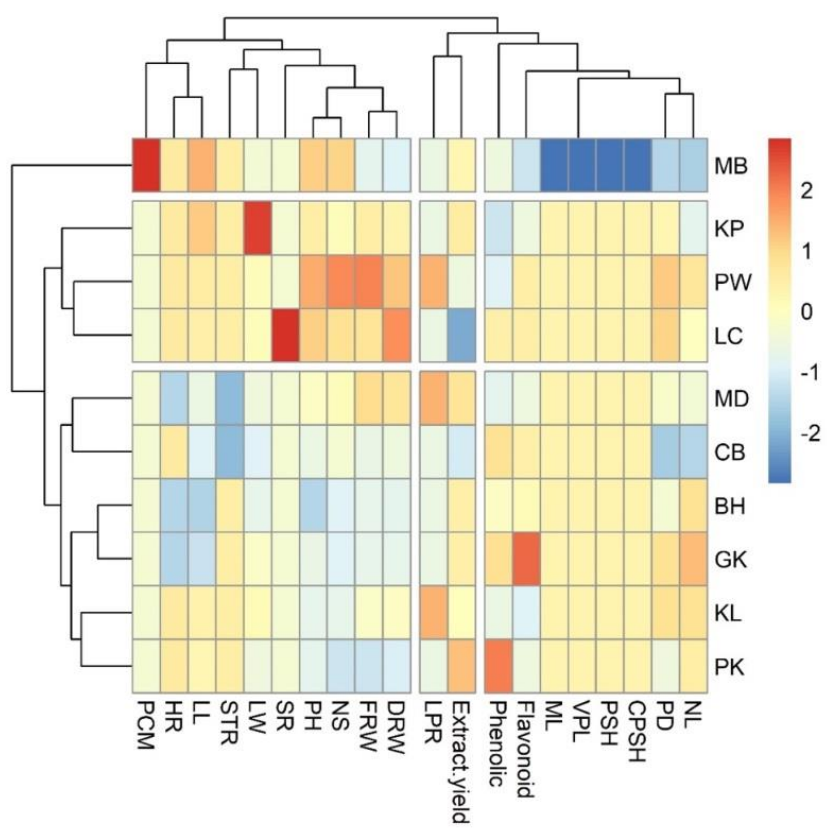

Figure 2. Heatmap and hierarchical cluster analysis of twodimensional relationships among $C$. aeruginosa accessions and traits mainly selected for agro-morphology, extract yield, total phenolic content and total flavonoid content. For an explanation of variable symbols, see Table 2.

\section{ACKNOWLEDGEMENTS}

The authors gratefully acknowledge financial support from the Ministry of Research, Technology and Higher Education of the Republic of Indonesia under the PTUPT (Penelitian Terapan Unggulan Perguruan Tinggi) grant; No. 1714/IT3.11/PN/2018. We appreciate Dr. G. John Acton for English proofreading and Mr. Topik Ridwan for botanical identification of the plant material used.

\section{REFERENCES}

Acquaah G. 2017. Plant Breeding, Principles. Academic Press, Oxford. Akarchariya N, Sirilun S, Julsrigival J, Chansakaowa S. 2017. Chemical profiling and antimicrobial activity of essential oil from Curcuma aeruginosa Roxb., Curcuma glans K. Larsen \& J. Mood and Curcuma cf. xanthorrhiza Roxb. collected in Thailand. Asian Pac J Trop Biomed 7: 881-885.

Alaklabi A, Arif IA, Ahamed A, Kumar RS, Idhayadhulla A. 2018. Evaluation of antioxidant and anticancer activities of chemical constituents of the Saururus chinensis root extracts. Saudi J Biol Sci 25: 1387-1392.

Al-Farsi M, Al-Amri A, Al-Hadhrami A, Al-Belushi S. 2018. Color, flavonoids, phenolics and antioxidants of Omani honey. Heliyon 4: e00874. DOI: 10.1016/j.heliyon.2018.e00874

Anandan S, Rudolph A, Speck T, Speck O. 2018. Comparative morphological and anatomical study of self-repair in succulent cylindrical plant organs. Flora 241: 1-7.

Bakić I V, Rakonjac VS, Čolić SD, Akšić MMF, Nikolić DT, Radović AR, Rahović DD. 2017. Agro-morphological characterisation and evaluation of a Serbian vineyard peach [Prunus persica (L.) Batsch] germplasm collection. Sci Hortic (Amsterdam) 225: 668-675.

Belaj A, León L, Satovic Z, la Rosa R de. 2011. Variability of wild olives (Olea europaea subsp. europaea var. sylvestris) analyzed by agromorphological traits and SSR markers. Sci Hortic (Amsterdam) 129: 561-569.

Chang C-C, Yang M-H, Wen H-M. 2002. Estimation of total flavonoid content in propolis by two complementary colorimetric methods. J Food Drug Anal 10: 178-182.

Jose S, Thomas TD. 2014. Comparative phytochemical and anti-bacterial studies of two indigenous medicinal plants Curcuma caesia Roxb. and Curcuma aeruginosa Roxb. Int J Green Pharm 8: 65-71.

Kamazeri TSAT, Samah OA, Taher M, Susanti D, Qaralleh H. 2012. Antimicrobial activity and essential oils of Curcuma aeruginosa, Curcuma mangga, and Zingiber cassumunar from Malaysia. Asian Pac J Trop Med 5: 202-209.

Kurasiak-Popowska D, Tomkowiak A, Człopińska M, Bocianowski J, Weigt D, Nawracała J. 2018. Analysis of yield and genetic similarity of Polish and Ukrainian Camelina sativa genotypes. Ind Crops Prod 123: 667-675.

Kwarteng AO, Abogoom J, Adu Amoah R, Nyadanu D, Nyam CK, Ghunney T, Awuah E, Ziyaaba JZ, Ogunsanya JO, Orhin EE, Asiedu DD. 2018. Phenomic characterization of twenty-four accessions of spider plant (Cleome gynandra L.) the Upper East region of Ghana. Sci Hortic (Amsterdam) 235: 124-131.

Mirto A, Iannuzzi F, Carillo P, Ciarmiello LF, Woodrow P, Fuggi A. 2018. Metabolic characterization and antioxidant activity in sweet cherry (Prunus avium L.) Campania accessions: Metabolic characterization of sweet cherry accessions. Food Chem 240: 559566.

Mishra R, Gupta AK, Kumar A, Lal RK, Saikia D, Chanotiya CS. 2018. Genetic diversity, essential oil composition, and in vitro antioxidant and antimicrobial activity of Curcuma longa L. germplasm collections. J Appl Res Med Aromat Plants 10: 75-84.

MoA [Kementerian Pertanian]. 2018. Sistem informasi database varietas tanaman. URL: http: //aplikasi.pertanian.go.id/varietas/tamu/hasilCari.asp $\quad\left[\begin{array}{ll}1 & \text { December }\end{array}\right.$ 2018]. [Indonesian]

Moektiwardoyo WM, Tjitraresmi A, Susilawati Y, Iskandar Y, Halimah E, Zahryanti D. 2014. The potential of dewa leaves (Gynura pseudochina (L) D.C) and temu ireng rhizomes (Curcuma aeruginosa 
Roxb.) as medicinal herbs for dengue fever treatment. Procedia Chem 13: $134-141$

Moghaddam M, Mehdizadeh L. 2015. Variability of total phenolic, flavonoid and rosmarinic acid content among Iranian basil accessions. LWT - Food Sci Technol 63: 535-540.

Moghaddam M, Pirbalouti AG. 2017. Agro-morphological and phytochemical diversity of Iranian Cuminum cyminum accessions. Ind Crops Prod 99: 205-213

Mohammadi M, Asadi-Gharneh HA. 2018. How the morphological properties of Mentha longifolia.(L.) Huds. may be affected by geographical differences. J Photochem Photobiol B Biol 178: 237242.

Neugart S, Baldermann S, Hanschen FS, Klopsch R, Wiesner-Reinhold M, Schreiner M. 2018. The intrinsic quality of brassicaceous vegetables: How secondary plant metabolites are affected by genetic, environmental, and agronomic factors. Sci Hortic (Amsterdam) 233 460-478.

Nurcholis W, Khumaida N, Syukur M, Bintang DM. 2017. Similarity analysis of 20 promising accessions of Curcuma aeruginosa Roxb. based on rhizome color, extract yield, and phytochemical contents. Indones J Agron 44: 315-321.

Nurcholis W, Khumaida N, Syukur M, Bintang M, Ardyani IDAA. 2015a. Phytochemical screening, antioxidant and cytotoxic activities in extracts of different rhizome parts from Curcuma aeruginosa Roxb. Int J Res Ayurveda Pharm 6: 634-637.

Nurcholis W, Khumaida N, Syukur M, Bintang M. 2016a. Variability of total phenolic and flavonoid content and antioxidant activity among 20 Curcuma aeruginosa Roxb. accessions of Indonesia. Asian J Biochem 11: 142-148.

Nurcholis W, Khumaida N, Syukur M, Bintang M. 2016b. Variability of curcuminoid content and lack of correlation with cytotoxicity in ethanolic extracts from 20 accessions of Curcuma aeruginosa RoxB. Asian Pacific J Trop Dis 6: 887-891.

Nurcholis W, Munshif AA, Ambarsari L. 2018. Xanthorrhizol contents, $\alpha$ glucosidase inhibition, and cytotoxic activities in ethyl acetate fraction of Curcuma zanthorrhiza accessions from indonesia. Rev Bras Farmacogn 28: 44-49.

Oliveira GL, Moreira D de L, Mendes ADR, Guimarães EF, Figueiredo LS, Kaplan MAC, Martins ER. 2013. Growth study and essential oil analysis of Piper aduncum from two sites of Cerrado biome of Minas Gerais State, Brazil. Rev Bras Farmacogn 23: 743-753.

Pandey G, Khatoon S, Pandey MM, Rawat AKS. 2018. Altitudinal variation of berberine, total phenolics and flavonoid content in Thalictrum foliolosum and their correlation with antimicrobial and antioxidant activities. J Ayurveda Integr Med 9: 169-176
Péroumal A, Adenet S, Rochefort K, Fahrasmane L, Aurore G. 2017. Variability of traits and bioactive compounds in the fruit and pulp of six mamey apple (Mammea americana L.) accessions. Food Chem 234: $269-275$

Petropulos VI, Bogeva E, Stafilov T, Stefova M, Siegmund B, Pabi N, Lankmayr E. 2014. Study of the influence of maceration time and oenological practices on the aroma profile of Vranec wines. Food Chem 165: 506-514.

PPV-FRA [Protection of Plant Varieties and Farmers' Rights Authority]. 2011. Guidelines for the Conduct of Test for Distinctiveness, Uniformity and Stability on Turmeric (Curcuma longa L .). Government of India, New Delhi.

Salgueiro L, Martins AP, Correia H. 2010. Raw materials: the importance of quality and safety. A review. Flavour Fragr J 25: 253-271.

Sasikumar B. 2005. Genetic resources of Curcuma: diversity, characterization and utilization. Plant Genet Resour Charact Util 3: 230-251.

Setiadi A, Khumaida N, Ardie SW. 2017. Diversity of some black turmeric (Curcuma aeruginosa Roxb.) accessions based on morphological characters. Indones J Agron 45: 71-78.

Srivilai J, Phimnuan P, Jaisabai J, Luangtoomma N, Waranuch N, Khorana N, Wisuitiprot W, Scholfield CN, Champachaisri K, Ingkaninan K. 2017. Curcuma aeruginosa Roxb. essential oil slows hair-growth and lightens skin in axillae; a randomised, double blinded trial. Phytomedicine 25: 29-38.

Suphrom N, Pumthong G, Khorana N, Waranuch N, Limpeanchob N, Ingkaninan K. 2012. Anti-androgenic effect of sesquiterpenes isolated from the rhizomes of Curcuma aeruginosa Roxb. Fitoterapia 83: 864871.

Syahid SF, Heryanto R. 2017. Morpho-agronomic characteristics of twelve accessions of white turmeric (Curcuma zedoaria) germplasm. Biodiversitas J Biol Divers 18: 269-274.

Thaina P, Tungcharoen P, Wongnawa M, Reanmongkol W, Subhadhirasakul S. 2009. Uterine relaxant effects of Curcuma aeruginosa Roxb. rhizome extracts. J Ethnopharmacol 121: 433-443.

Udavant PB, Satyanarayana SV, Upasani CD. 2012. Preliminary screening of Cuscuta reflexa stems for anti-inflammatory and cytotoxic activity. Asian Pac J Trop Biomed 2: S1303-S1307.

Wang L, Bai P, Yuan X, Chen H, Wang S, Chen X, Cheng X. 2018. Genetic diversity assessment of a set of introduced mung bean accessions (Vigna radiata L.). Crop J 6: 207-213.

Wan-Ibrahim WI, Sidik K, Kuppusamy UR. 2010. A high antioxidant level in edible plants is associated with genotoxic properties. Food Chem 122: 1139-1144. 